Original Research Paper

\title{
Pemberdayaan Ekonomi Nelayan Rajungan Melalui Pengembangan Teknologi Alat Tangkap Bubu fi Desa Pemongkong Kabupaten Lombok Timur
}

\author{
Syarif Husni $^{1 *}$, M. Yusuf ${ }^{1}$, Muhammad Nursan ${ }^{1}$, Aeko Fria Utama FR ${ }^{1}$ \\ ${ }^{1}$ Program Studi Agribisnis Fakultas Pertanian Universitas Mataram, Mataram, Indonesia
}

https://doi.org/10.29303/jpmpi.v3i2.1143

Sitasi: Husni, S., Yusuf, M., Nursan, M \& Utama FR, A. . U. (2021). Pemberdayaan Ekonomi Nelayan Rajungan Melalui Pengembangan Teknologi Alat Tangkap Bubu fi Desa Pemongkong Kabupaten Lombok Timur. Jurnal Pengabdian Magister Pendidikan IPA 4(4)

\author{
Article history \\ Received: 02 Oktober 2021 \\ Revised: 20 Oktober 2021 \\ Accepted: 09 November 2021 \\ *Corresponding Author: Syarif \\ Husni, Program Studi \\ Agribisnis Fakultas Pertanian \\ Universitas Mataram, Mataram, \\ Indonesia; \\ Email: \\ syarifhusni1964@gmail.com
}

\begin{abstract}
Desa Pemongkong sebagai salah satu desa yang terletak di pesisir bagian barat Teluk Eka Kabupaten lombok Timur, sebagian besar masyarakatnya menggantungkan hidupnya pada sektor perikanan yakni sebagai nelayan tradisional. Selain sebagai nelayan penangkap ikan juga sebagai nelayan penangkap rajungan. Saat ini alat tangkap yang dioperasikan nelayan untuk menangkap rajungan didominasi jaring tasik. Penggunaan alat ini tidak efisien secara ekonomi dan tidak ramah lingkungan. Oleh karena itu perlu dilakukan introdusksi alat tangkap BUBU, selain mampu meningkatkan ekonomi nelayan rajungan juga penggunaan alat tangkap ini ramah lingkungan. Tujuan PPM adalah melakukan sosialisasi teknologi alat tangkap ramah lingkungan dan introdusir teknologi alat tangkap bubu pada kelompok nelayan rajungan di Desa Pemongkong Kabupaten Lombok Timur. Metode pelaksanaan pemberdayaan ekonomi nelayan rajungan yaitu melalui metode Sosialisasi dan metode FGD. Hasil pengabdian menunjukkan: a) Adopsi penggunaan alat tangkap BUBU oleh nelayan dapat ditingkatkan melalui skema kemitraan dan bantuan pemerintah b) Introdusir alat tangkap BUBU di kalangan nelayan diharapkan dapat diadopsi untuk meningkatkan pendapatan dan kelestarian lingkungan.
\end{abstract}

Kata Kunci: pemberdayaan, kelestarian lingkungan

\section{Pendahuluan}

Tantangan untuk memelihara sumberdaya secara berkelanjutan merupakan permasalahan yang cukupkompleks dalam pembangunan perikanan. Sumberdaya perikanandikategorikan sebagai sumberdaya yangdapat pulih, namun pertanyaan yang sering muncul adalah seberapa besar ikan yang dapat dimanfaatkan tanpa harus menimbulkan dampak negatif untuk masa mendatang. Keberlanjutan merupakan kata kunci dalam pembangunan perikanan yang diharapkan dapat memperbaiki kondisi sumberdaya dan kesejahteraan masyarakat perikanan itu sendiri (Fauzi dan Anna, 2002).

Dahuri (2002) mengemukakan bahwa pemanfaatan berkelanjutan suatu sumber daya harus mencakup tiga hal, yaitu ekologi (lingkungan), ekonomi, dan sosial. Selanjutnya dikatakan bahwa pengelolaan perikanan pada tahap awal ketika stok masih melimpah bertujuan pada pengembangan kegiatan ekploitasi sumber daya untuk memaksimumkan produksi dan produktivitas. Pada tahap selanjutnya, ketika pemanfaatan sumber daya perikanan mulai mengancam kelestarian stok ikan tersebut karena semakin bertambahnya pihakpihak yang terlibat, pengelolaan perikanan biasanya mulai memperlihatkan unsur sosial (keadilan) dan lingkungan agar pemanfaatan sumber daya tersebut dapat berkelanjutan. Strategi yang diterapkan pada tahap ini pada umumnya bertujuan konservasi.

Kepiting Rajungan (Portunus pelagicus) merupakan salah satu sumberdaya perikanan yang cukup penting untuk menambah pendapatan dan 
pemenuhan kebutuhan protein hewani. Rajungan memiliki nilai ekonomis penting dan telah diekspor ke berbagai negara dalam bentuk segar maupun olahan. Tembusnya di pasar ekspor menyebabkan harga rajungan semakin tinggi di pasar domestik maupun ekspor, sehingga merangsang nelayan untuk mengeksploitasi sumberdaya tersebut. Apabila hal ini tidak diimbangi dengan pengelolaan yang tepat akan menyebabkan terjadinya pengurasan (depletion) terhadap sumberdaya tersebut, sehingga tidak menutup kemungkinan akan terjadinya kepunahan (Adam, Firman dan Anwar, 2016).

Rajungan merupakan salah satu komoditi perikanan yang bernilai ekonomis tinggi, karena komoditi ini sangat diminati oleh masyarakat, baik dalam negeri maupun luar negeri. Hal ini terlihat dari hasil ekspor Rajungan yang mengalami kenaikan setiap tahun (Statistik Ekspor Impor Direktorat Jenderal Penguatan Daya Saing Produk Kelautan dan Perikanan, 2016).

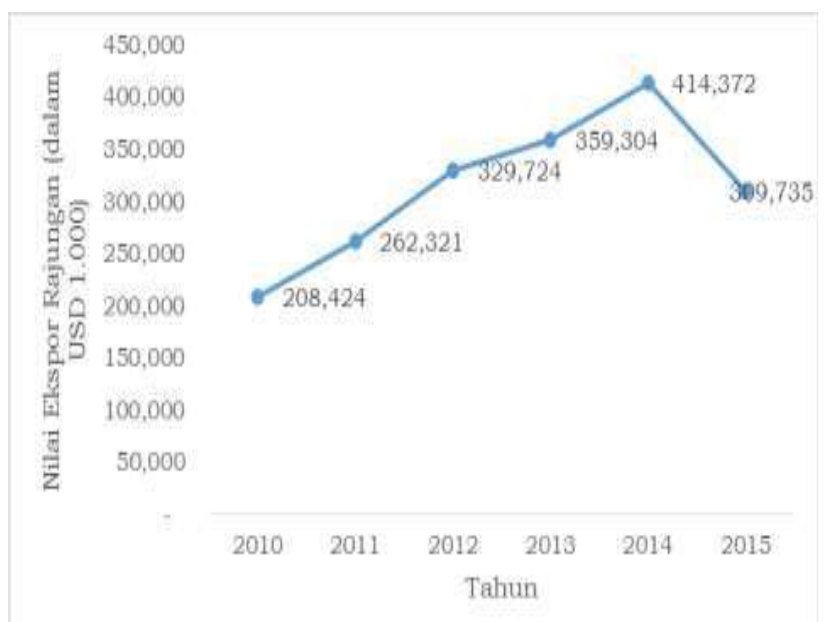

Gambar 1. Nilai Ekspor Rajungan tahun 2010-2015 (KKP, 2016)

Sementara itu Propinsi NTB menempati posisi ke-4 dalam produksi rajungan di Indonesia setelah Sumatera Utara, Lampung, dan Sulawesi Selatan dengan jumlah produsksii mencapai 5.000 ton (Statistik Perikanan, 2015). Salah satu penghasil rajungan yang terbesar di Pulau Lombok berada di Kawasan Teluk Ekas Kabupaten Lombok Timur

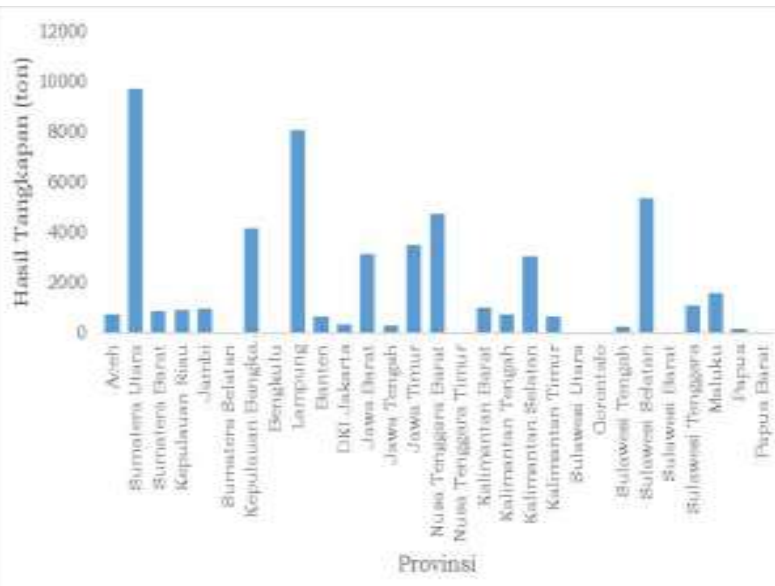

Gambar 2. Produksi Perikanan Rajungan di Indonesia tahun 2014 (KKP, 2016)

Kawasan pesisir Teluk Ekas terletak diantara Kabupaten Lombok Timur dan Lombok Tengah. Teluk tersebut dikelilingi oleh enam desa dari dua kecamatan. Desa Mertak dan Desa Bile Lando (Kecamatan Praya Timur, Kabupaten Lombok Tengah), Desa Batunampar Selatan, Desa Sukaraja, Desa Jerowaru, dan Desa Pemongkong (Kecamatan Jerowaru, Kabupaten Lombok Timur) dengan luas 5.643,69 ha. Lokasi teluk terlindung dari arus dan gelombang besar, karena adanya daerah karang di mulut teluk yang dapat berfungsi sebagai pemecah gelombang.

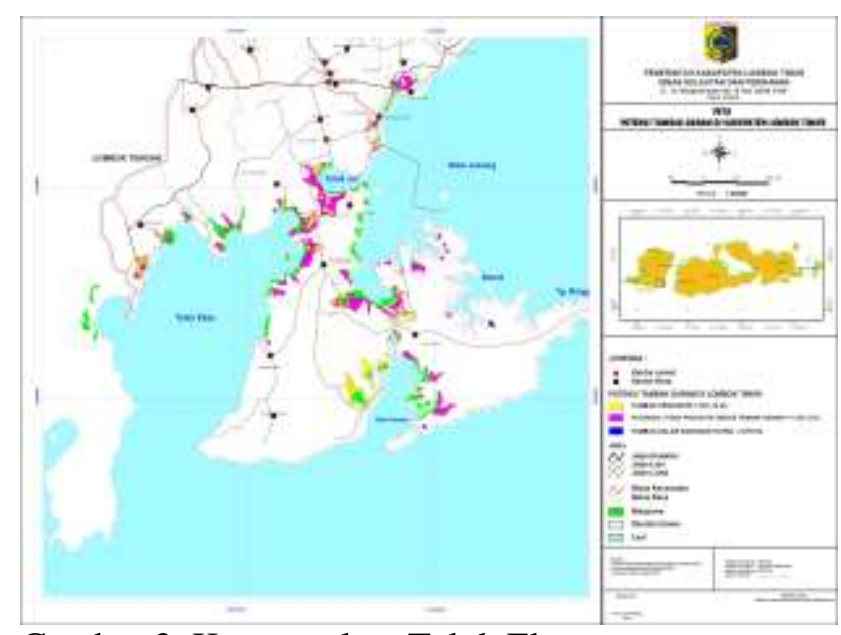

Gambar 3. Kawasan laut Teluk Ekas

Desa Pemongkong sebagai salah satu desa yang terletak di pesisir bagian barat Teluk Ekas dan termasuk dalam Kecamatan Jerowaru Kabupaten Lombok Timur, sebagian besar masyarakatnya menggantungkan hidup pada sektor perikanan yaitu sebagai nelayan tradisional. Selain sebagai nelayan 
penangkap ikan juga sebagai besar adalah nelayan penangkap rajungan sebanyak 500 orang. Alat tangkap yang dipakai untuk menangkap rajungan adalah jaring tasik dengan hasil tangkapan berkisar 3-4 kg per hari, dengan harga rajungan $\mathrm{Rp}$ $70.000 / \mathrm{kg}$, dan bila dikurangi dengan biaya operasional untuk BBM Rp 30.000, maka pendapatan yang diperoleh sekitar $\mathrm{Rp} 180.000-$ 250.000 per hari. Jaring tasik yang dioperasikan tidak tahan lama maksimal satu bulan, sehingga nelayan mengganti dengan jaring yang baru atau mengganti bagian jaring yang rusak. Menurut Zarochman (2006) dalam Brefin Mushtaf Adam (2012) penggunaan alat tangkap jaring tasik disamping kurang ramah lingkungan (kurang selektif) juga kualitas hasil tangkapannya relative rendah (umumnya hasil tangkapan sudah mati dan rusak) sehingga tangkapan sudah tidak bernilai. Disamping itu metode penangkapan tersebut cenderung akan merusak habitat dan komunitas rajungan pun menjadi cepat berkurang atau punah.

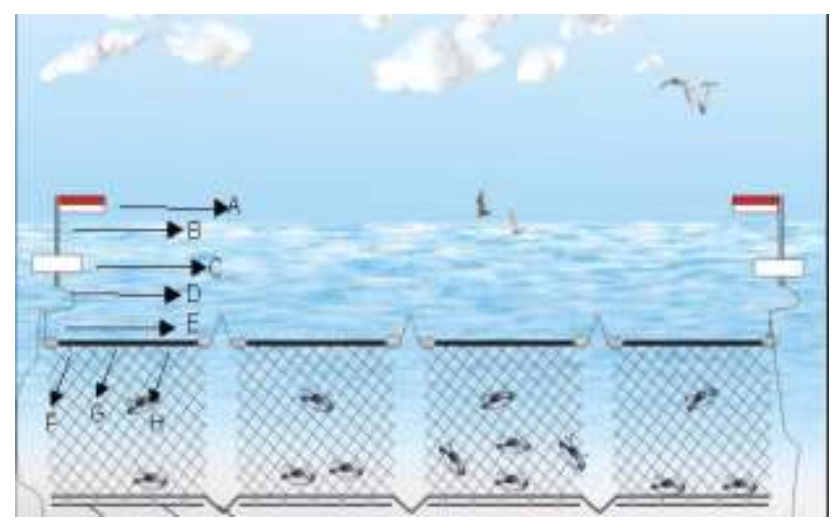

Gambar 4. Ilustrasi pengoperasian Alat tangkap jaring /tasik

Oleh karena itu untuk meningkat pendapatan nelayan rajungan di Desa Pemongkong perlu dilakukan introdusir alat tangkap rajungan untuk yang mampu meningkatkan hasil tangkapan yaitu BUBU. Alat tangkap ini mampu meningkatkan produksi menjadi 8-10 kg per hari. Alat tangkap Bubu lebih tahan lama lebih dari satu tahun dan lebih mudah dioperasikan dibandingkan dengan jaring tasik. Selain itu alat tangkap tersebut lebih mudah pengoperasian dan ramah lingkungan dibandingkan dengan jaring tasik.

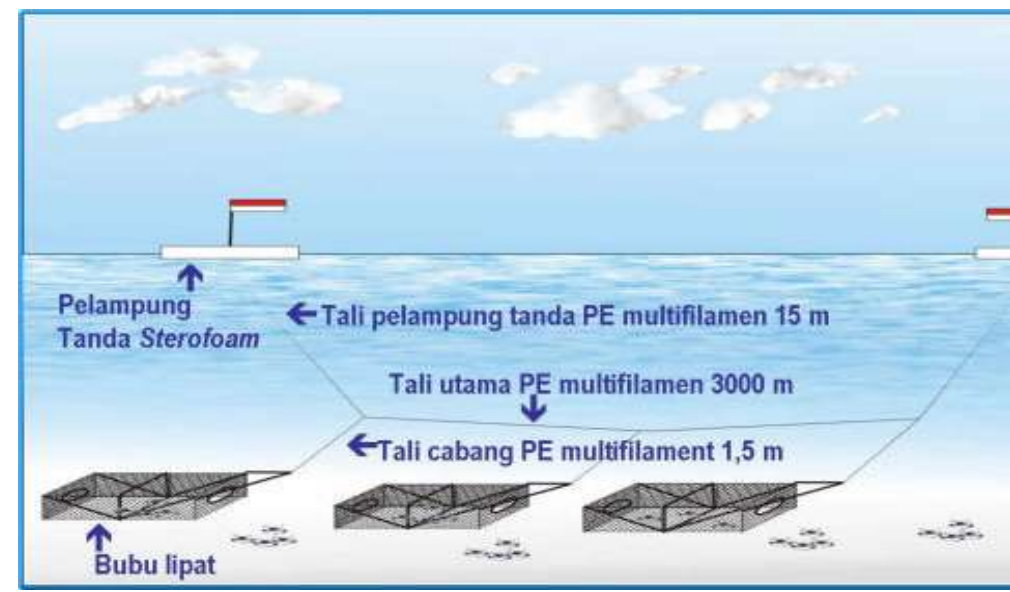

Gambar 5. Ilustrasi pengoperasian alat Tangkap Bubu

Untuk meningkatkan pendapatan nelayan rajungan sekaligus penggunaaan alat tangkap yang ramah lingkungan, maka perlu dikembangkan di kalangan nelayan dengan mengadopsi alat tangkap BUBU. Selain itu alat tangkap ini lebih mudah dalam penggunaannya dibandingkan dengan jaring tasik.

Tujuan pengabdian kepada masyarakat adalah 1) melaksanakan sosialisasi teknologi alat tangkap bubu kepada nelayan rajungan, dan 2) Introdusir teknologi alat tangkap bubu pada kelompok nelayan rajungan di Desa Pemongkong Kabupaten Lombok Timur

Manfaat pengabdian adalah menjadi alternatif bagi nelayan dalam penerapan teknologi alat tangkap ramah lingkugan dan meningkatkan ekonomi nelayan rajungan

\section{Metode}

Metode pelaksanaan penyusunan Rencana Pengelolaan sumberdaya Pesisir berbasis masyarakat ini terdiri Metode Sosialisasi dan Focus Group Discussion (FGD). Selanjutnya Metode Focus Group Discussion (FGD). Diskusi Kelompok Terarah merupakan suatu proses pengumpulan informasi mengenai suatu masalah tertentu yang sangat spesifik (Irwanto, 2007). Diskusi kelompok terarah adalah wawancara dari sekelompok kecil orang yang dipimpin seorang narasumber atau moderator yang mendorong peserta untuk berbicara terbuka dan spontan tentang hal yang dianggap penting dan berkaitan dengan topik saat itu. 
Tujuan dari Diskusi Kelompok Terarah itu sendiri adalah untuk memperoleh masukan atau informasi mengenai permasalahan yang bersifat lokal dan spesifik. Penyelesaian masalah ini ditentukan oleh pihak lain setelah informasi berhasil dikumpulkan dan dianalisis. Proses FGD dengan nelayan rajungan dalam rangkautntuk menggali informasi tentang kondisi alat dan armada tangkap, biaya produksi melaut, jumlah hasil tangkapan rajungan, kondisi habitat rajungan saat ini, dan peran pemerintah dalam pengambilan kebijakan baik aktivitas nelayan maupun pemasaran rajungan.

Kemudian kegiatan terakhir adalah introdusir alat tangkap bubu ke kelompok nelayan dengan tujuan agar penggunaan bubu sebagai alat tangkap rajungan dapat diadopsi nelayan, sehingga pada akhirnya nanti hasul tangkapan nelayan meningkat dan ekonomi nelayan membaik.

\section{Hasil dan Pembahasan}

\section{Sosialisasi Rajungan dan Alat Tangkap Bubu}

Kegiatan sosialisasi dan FGD serta introdusir alat tangkap bubu dilaksanakan di Dusun Ujung pada hari Minggu, tangga 11 Juli 2021bertempat di rumah Kepala Dusun Ujung (Bapak Ahyar Rasyidi). Peserta yang hadir sebanyak 30 orang yang merupakan perwakilan nelayan rajungan.

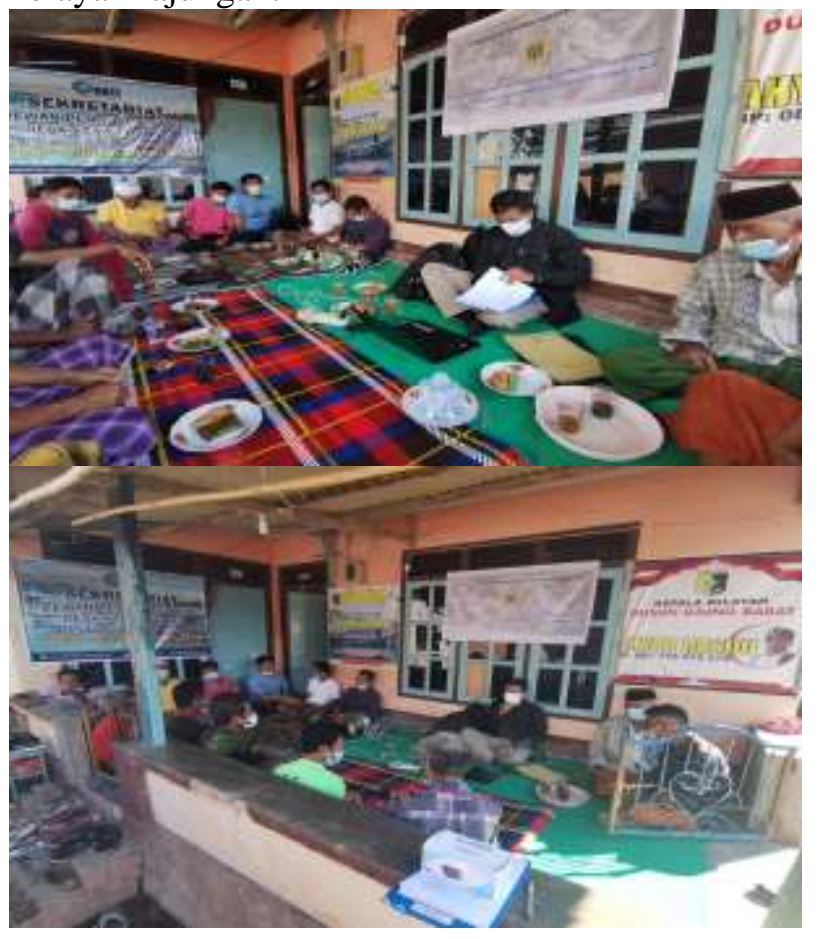

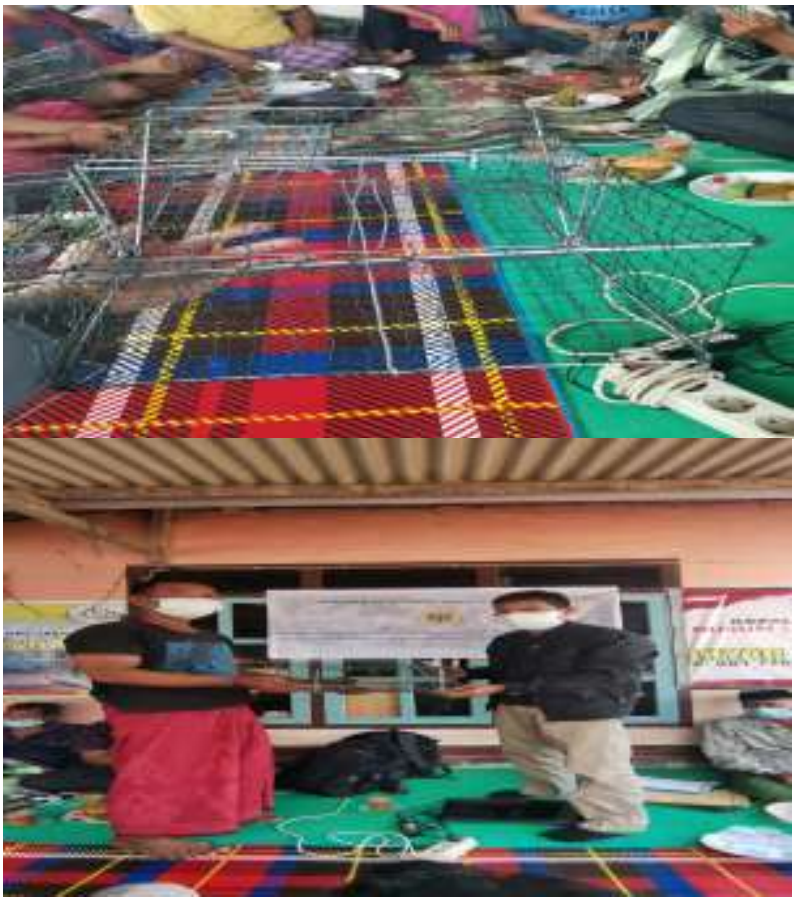

Gambar 6 . Kegiatan Sosialisasi, FGD dan introdusir alat tangkap bubu

Secara garis besar hasil diskusi melalui sosialisasi dan FGD adalah sebagai berikut:

\section{Kondisi Rajungan saat ini}

Rajungan hasil tangkapan para nelayan dijual pada para pengumpul (bakul). Para pengumpul ini menjual rajungannya kepada para bandar besar yang merupakan agen pembelian dari perusahaan-perusahaan besar (eksportir) rajungan. Oleh karena itu produksi rajungan sering tidak tercatat oleh petugas dari Dinas Perikanan setempat. Tidak adanya data produksi ini mengakibatkan sulitnya mengetahui besar produksi yang dihasilkan. Di lain pihak, pasar yang luas dan harga yang tinggi ini menjadi pemicu berkembangnya perikanan rajungan. Hingga saat ini besarnya tingkat pemanfaatan dan perdagangan rajungan tidak diimbangi dengan pengetahuan tentang cara melestarikan sumberdaya tersebut. Hal ini dapat berakibat pada terjadinya penurunan stok sumberdaya rajungan. Pengetahuan tentang cara melestarikan sumberdaya rajungan dapat meliputi pengetahuan tentang berapa besar tingkat rekruitmen, berapa besar tingkat mortalitas, kapan waktu yang tepat melakukan penangkapan, berapa ukuran yang layak tangkap, berapa ukuran pertama matang gonad, dan bagaimana karakteristik habitatnya (Santoso, et.al, 2016) 
Perkawinan rajungan terjadi pada musim panas. Saat itu akan terlihat jantan yang mendekat dan melekatkan diri pada betina, kemudian menghabiskan beberapa waktu dengan berenang. Perkawinan tersebut akan menghasilkan larva yang mirip dengan udang. Pada bagian kepalanya terdapat benda seperti tanduk yang memanjang, matanya besar, dan di bagian ujung kakinya terdapat rambut-rambut halus.

Larva yang baru menetas berada dalam tahap zoea. Tahap tersebut terbagi menjadi empat tingkat, yakni zoea 1 , zoea 2 , zoea 3 , dan zoea 4 . Tahap zoea berlangsung selama 9 sampai 12 hari. Seteah itu, tahap kehidupan biota berubah ke tahap megalopa dengan bentuk yang berbeda. Tahap megalopa akan berlangsung selama 4 sampai 6 hari.

Saat masih larva, rajungan hidup seperti plankton karena hidupnya berenang dan terbawa arus. Sementara itu, pada tahap megalopa, bentuk biota ini sudah mulai mirip dengan rajungan, tubuhnya semakin melebar, bagian kaki dan capitannya sudah semakin jelas, serta bagian matanya membesar.

Setelah tahap megalopa, rajungan memasuki tahap juvenil, di mana bentuk tubuhnya sudah berbentuk seperti rajungan muda. Pada tahap ini biota laut ini sudah bisa dipanen dalam bentuk benih, kemudian dipelihara di tambak pembesaran.

Habitat asli biota laut ini adalah pantai bersubstrat pasir, pasir berlumpur, dan pulau berkarang. Rajungan hidup di daerah estuaria kemudian bermigrasi ke perairan dengan tingkat salinitas yang tinggi untuk menetaskan telurnya. Setelah rajungan mencapai tahap juvenil, biota akan kembali ke estuaria.

Rajungan berasal dari jenis kepiting yang cukup populer dan sudah menjadi komoditas hasil laut yang cukup digemari sebagai salah satu bahan makanan yang lezat dan bergizi ( https://www.pertanianku.com/siklus-hiduprajungan/).

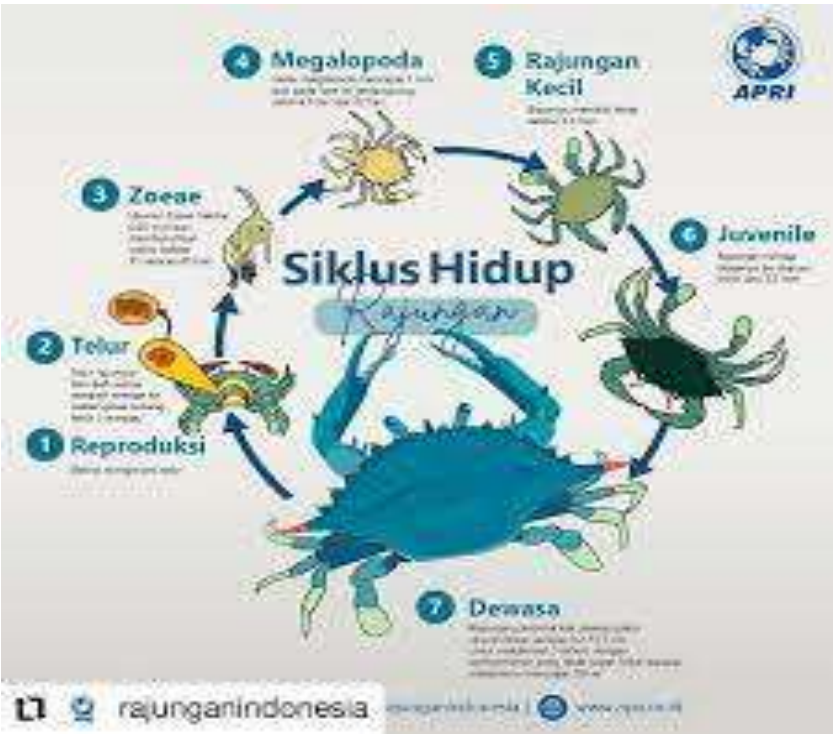

Gambar 6. Siklus hidup rajungan

\section{a. Ciri Ciri Rajungan}

Ciri Ciri Rajungan - Sebagian Orang susah untuk megenali rajungan dengan kepiting. Kedua hewan laut tersebut terlihat sama tetapi secara ciri ciri sebenarnya keduanya adalah berbeda. Dimana Perbedaanya tersebut akan di bawas dalam ciri ciri pada rajungan.

Secara umum morfologi rajungan berbeda dengan kepiting bakau, di mana rajungan (Portunus pelagicus) memiliki bentuk tubuh yang lebih ramping dengan capit yang lebih panjang dan memiliki berbagai warna yang menarik pada karapasnya. Duri akhir pada kedua sisi karapas relatif lebih panjang dan lebih runcing.

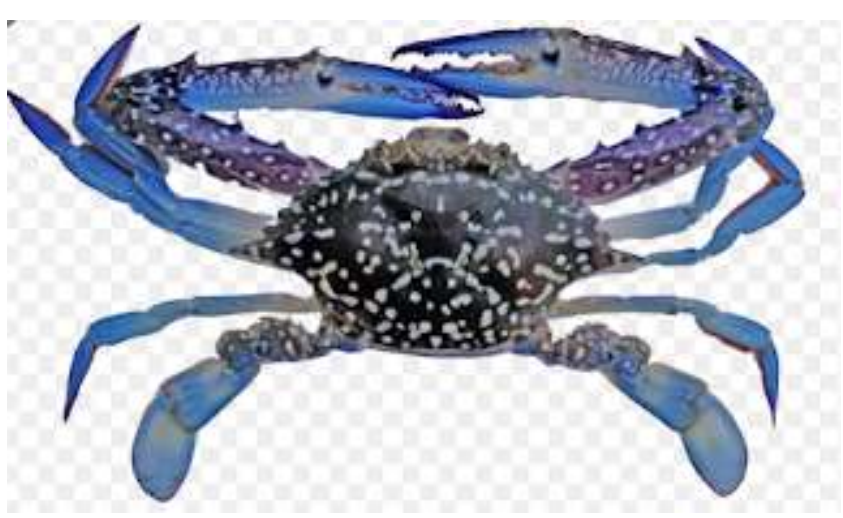

Gambar 7. Morfologi Rajungan

Rajungan hanya hidup pada lingkungan air laut dan tidak dapat hidup pada kondisi tanpa air. Bila kepiting hidup di perairan payau, seperti di hutan bakau atau di pematang tambak, rajungan 
hidup di dalam laut. Rajungan memang tergolong hewan yang bermukim di dasar laut, tapi malam hari suka naik ke permukaan untuk cari makan. Makanya rajungan disebut juga "swimming crab" alias kepiting yang bisa berenang.

Dengan melihat warna dari karapas dan jumlah duri pada karapasnya, maka dengan mudah dapat dibedakan dengan kepiting bakau. Rajungan (P. pelagicus) memiliki karapas berbentuk bulat pipih, sebelah kiri-kanan mata terdapat duri sembilan buah, di mana duri yang terakhir berukuran lebih panjang.

Rajungan mempunyai 5 pasang kaki, yang terdiri atas 1 pasang kaki (capit) berfungsi sebagai pemegang dan memasukkan makanan kedalam mulutnya, 3 pasang kaki sebagai kaki jalan dan sepasang kaki terakhir mengalami modifikasi menjadi alat renang yang ujungnya menjadi pipih dan membundar seperti dayung. Oleh sebab itu rajungan digolongkan kedalam kepiting berenang (swimming crab). Kaki jalan pertama tersusun atas daktilus yang berfungsi sebagai capit, propodos, karpus, dan merus.

Induk rajungan mempunyai capit yang lebih panjang dari kepiting bakau, dan karapasnya memiliki duri sebanyak 9 buah yang terdapat pada sebelah kanan kiri mata. Bobot rajungan dapat mencapai 400 gram, dengan ukuran karapas sekitar 300 mm (12 inchi), Rajungan bisa mencapai panjang $18 \mathrm{~cm}$, capitnya kokoh, panjang dan berduri-duri.

Rajungan mempunyai karapas berbentuk bulat pipih dengan warna yang sangat menarik. Ukuran karapas lebih besar ke arah samping dengan permukaan yang tidak terlalu jelas pembagian daerahnya. Sebelah kiri dan kanan karapasnya terdapat duri besar, jumlah duri sisi belakang matanya sebanyak 9, 6, 5 atau 4 dan antara matanya terdapat 4 buah duri besar.

Warna rajungan jantan adalah dasar biru dengan bercak putih, sedangkan rajungan betina berwarna dasar hijau kotor dengan bercak putih kotor. Induk rajungan mempunyai capit yang lebih panjang dari kepiting bakau, dan karapasnya memiliki duri sebanyak 9 buah yang terdapat pada sebelah kanan kiri mata.

Bobot rajungan dapat mencapai $400 \mathrm{~g}$, dengan ukuran karapas sekitar 300 mm (12 inchi). Ukuran rajungan antara yang jantan dan betina berbeda pada umur yang sama. Yang jantan lebih besar dan berwarna lebih cerah serta berpigmen biru terang. Sedang yang betina berwarna sedikit lebih coklat

Nontji (1986) menyatakan rajungan mempunyai 5 pasang kaki jalan, di mana kaki jalan pertama ukurannya besar, memiliki capit dan kaki jalan terakhir mengalami modifikasi sebagai alat berenang. Kaki jalan pertama rajungan tersusun atas daktilus yang berfungsi sebagai capit, propodos, karpus, dan merus. Sedangkan pada kaki kelimayang mengalami modifikasi pada daktilus menyerupai dayung untuk berenang dan berbentuk pipih.

Dari beberapa jenis kepiting yang dapat berenang (swimming crab), sebagian besar merupakan jenis rajungan. Sebagai contoh yang banyak terdapat di Teluk Jakarta adalah 7 jenis rajungan seperti Portunus pelagicus, $P$. sanguinolentus, Thalamita crenata, Thalamita danae, Charybdis cruciata, Charibdis natator, Podophthalmus vigil (Anonim, 1973).

Sementara beberapa informasi lain menyebutkan bahwa jenis rajungan terdiri atas 11 jenis seperti Portunus pelagicus Linn, P. sanguinolentus Herbst, P. sanguinus, P. trituberculatus, P. gladiator, P. hastatoides, Thalamita crenata Latr., Thalamita danae Stimpson, Charybdis cruciata, Charibdis natator Herbst, Podophthalmus vigil Fabr., (Nakamura, 1990; Soim, 1996; Supriyatna, 1999), sedangkan P. trituberculatus banyak ditemukan di Jepang, Cina, Taiwan, dan Korea. Nilai gizi dari bagian tubuh jenis kepiting yang dapat dimakan (edible portion) mengandung protein $65,72 \%$; mineral $7,5 \%$; dan lemak 0,88\% (Soim, 1996).

\section{b. Habitat dan Penyebaran Rajungan}

Rajungan (swimming crab) memiliki tempat hidup yang berbeda dengan jenis kepiting pada umumnya seperti kepiting bakau (Scylla serrata), tetapi memiliki tingkah laku yang hampir sama dengan kepiting. Coleman (1991) melaporkan bahwa rajungan (Portunus pelagicus) merupakan jenis kepiting perenang yang juga mendiami dasar lumpur berpasir sebagai tempat berlindung.

Jenis rajungan ini banyak terdapat pada lautan Indo-Pasifik dan India. Sementara itu informasi dari panti benih rajungan milik swasta menyebutkan bahwa tempat penangkapan rajungan terdapat di daerah Gilimanuk (pantai utara Bali), Pengambengan (pantai selatan Bali), Muncar (pantai selatan Jawa Timur), Pasuruan (pantai utara 
Jawa Timur), daerah Lampung, daerah Medan, dan daerah Kalimantan Barat.

(1980) memberikan informasi bahwa habitat rajungan adalah pada pantai bersubstrat pasir, pasir berlumpur, dan di pulau berkarang, juga berenang dari dekat permukaan laut (sekitar $1 \mathrm{~m}$ ) sampai kedalaman 56 meter. Rajungan hidup di daerah estuaria kemudian bermigrasi ke perairan yang bersalinitas lebih tinggi untuk menetaskan telurnya, dan setelah mencapai rajungan muda akan kembali ke estuaria (Nybakken, 1986).

Rajungan banyak menghabiskan hidupnya dengan membenamkan tubuhnya di permukaan pasir dan hanya menonjolkan matanya untuk menunggu ikan dan jenis invertebrata lainnya yang mencoba mendekati untuk diserang atau dimangsa (https://perikanan38.blogspot.com/2021/02/ciriciri-rajungan.html\#super)

\section{Bubu (Trap)}

Perikanan terutama perikanan tangkap bersifat quick yielding (cepat memberikan hasil) dan profitable, meskipun berisiko. Namun demikian, kenyataanya pelaku usaha perikanan tangkap, terutama nelayan pada umumnya berpendapatan rendah, miskin dan kurang sejahtera.

Beberapapermasalahan yang dihadapi oleh $n$ elayan dalam kegiatan penangkapan adalah ket ergantungan terhadap kondisi ketersediaan sumberdaya ikan dan kondisi alam. Peningkatan jumlah nelayan mencapai $50 \%$ dalam satu dasa warsa, hal tersebut menyebabkan meningkatkan tekanan yang mempercepat kerusakan sumberdaya alam dan penurunan keanekaragaman hayati. Pada beberapa daerah bahkan sudah mengalami lebih tangkap/over fishing yang sangat nyata.

Terbitnya Peraturan Menteri Kelautan dan Perlkanan No. 02 Tahun 2015 yang melarang penggunaan alat tangkap Pukat hela (Trawls) dan alat tangkap Pukat tarik (Seine Nets) di Wilayah Pengelolaan Perikanan Negara Republik Indonesia merupakan gerakan kesadaran Pemerintah melalui menteri Kelautan dan Perikanan kepada masyarakat luas untuk lebih serius memanfaatkan, men jaga, dan mengelola sumberdaya alam laut yang memiliki potensi besar yang terkandung didalamnya.

Bubu (Trap) adalah salah satu alat tangkap yang digunakan untuk menangkap Rajungan. Rajungan yang tertangkap dengan alat tangkap
Bubu masih dalam kondisi hidup dan segar sehingga mutu hasil tangkapan terjamin. Rajungan (Portunus pelagicus) merupakan komiditas ekonomis penting perikanan, dengan harga jual yang tinggi jika dalam kondisi hidup. Funnel (pintu masuk) pada Bubu merupakan salah satu penentu keberhasilan biota (Rajungan) terjebak masuk kedalamnya.

Bubu merupakan alat penangkap ikan yang tergolong ke dalam kelompok perangkap (traps). Alat ini bersifat pasif, yakni memerangkap ikan untuk masuk ke dalamnya namun sulit untuk meloloskan diri. Adapun bubu yang digunakan untuk menangkap rajungan termasuk ke dalam jenis bubu dasar.

Salah satu solusi untuk menjaga kelestarian sumberdaya ikan di perairan laut, maka perlu adanya suatu terobosan yaitu dengan desain alat tangkap yang ramah lingkungan. Salah satu jenis alat tangkap ramah lingkungan adalah Bubu (fish trap). Pada tahun 1995, PBB melalui FAO (Food Agriculture Organization) menetapkan suatu tata cara bagi kegiatan penangkapan ikan yang bertanggung jawab yang disebut CCRF (Code of Conduct for Resposible Fisheries). Dalam CCRF ada 9 (sembilan) kriteria bagi teknologi penangkapan ikan ramah lingkungan, yaitu :

a. Memiliki selektivitas tinggi. Artinya, alat tangkap tersebut diupayakan hanya dapat menangkap ikan/organisme lain yang menjadi sasaran penangkapan saja. Ada dua macam selektivitas yang menjadi sub kriteria, yaitu selektivitas ukuran dan selektivitas jenis.

b. Hasil tangkapan sampingan (bycatch) rendah. Bycatch merupakan tangkapan ikan non tar get yang tertangkap dalam proses penangka pan, dimana tangkapan sampingan ini tertangkap bersamaan dengan ikan target penangkapan.

c. Hasil tangkapan berkualitas tinggi. Hasil tangkapan yang diperoleh masih mempunyai kualitas mutu yang baik pada saat sampai di tangan konsumen/ pengguna.

d. Tidak merusak habitat / lingkungan(destruktif). Alat tangkap yang tidak merusak habitat dapat dilihat dari metode penangkapan ikan dan pengoperasian alat tangkap, baik yang dioperasikan di dasar perairan, di tengah perairan maupun di permukaan perairan. 
e. Mempertahankan keanekaragaman hayati. Dampak terhadap biodiversity merupakan $\mathrm{p}$ engaruh buruk dari pengoperasian alat tang kap terhadap keanekaragaman hayati yang ada di lingkungan tempat pengoperasian alat tangkap. Alat tangkap yang digunakan tidak dimodifikasi, selain itu tidak menggunakan bahan yang merusak lingkungan seperti penggunaan racun, bom, potas dan lainnya. Hal ini dapat dapat merusak kelangsungan kehidupan biota perairan (Ikan, Plankton, Benthos dan lainnya).

f. Tidak menangkap spesies yang dilindungi/terancam punah. Alat tangkap dikatakan berbahaya terhadap spesies yang dilindungi apabila dalam pengoperasiannya tertangkap spesies yang dilindungi dalam frekuensi relatif besar. Dalam pengoperasian alat tangkap tidak menangkap ikan yang dilindungi atau ikan yang dilarang oleh pemerintah untuk ditangkap misalnya penyu, dugong-dugong dan lumba-lumba.

g. Pengoperasian API tidak membahayakan keselamatan. Tingkat bahaya atau resiko yang diterima oleh nelayan dalam mengoperasikan alat tangkap tergantung pada jenis alat tangkap yang digunakan dan keahlian nelayan dalam mengoperasikan alat tangkap tersebut.

h. Tidak melakukan penangkapan di daerah terlarang. Tidak menangkap ikan di daerah penangkapan yang dinyatakan: lebih tangkap, di kawasan konservasi, di daerah penangkapan yang ditutup, di daerah yang tercemar dengan logam berat dan di kawasan perairan lainnya yang dinyatakan terlarang, seperti alur masuk pelabuhan.

i. Dapat diterima secara social. Suatu alat diterima secara sosial oleh masyarakat apabila biaya investasi murah, menguntungkan secara ekonomi, tidak bertentangan dengan budaya setempat, tidak bertentangan dengan peraturan yang ada.

Bubu adalah alat tangkap yang umum dikenal dikalangan nelayan, yang berupa jebakan, dan bersifat pasif. Bubu sering juga disebut perangkap "traps" dan penghadang "guiding barriers". Alat ini berbentuk kurungan seperti ruangan tertutup sehingga ikan tidak dapat keluar. Bubu merupakan alat tangkap pasif, tradisional yang berupa perangkap ikan tersebut dari bubu, rotan, kawat, besi, jaring, kayu dan plastik yang dijalin sedemikian rupa sehingga ikan yang masuk tidak dapat keluar. Prinsip dasar dari bubu adalah menjebak penglihatan ikan sehingga ikan tersebut terperangkap di dalamnya, alat ini sering diberi namafishing pots ataufishing basket (Brandt, 1984).

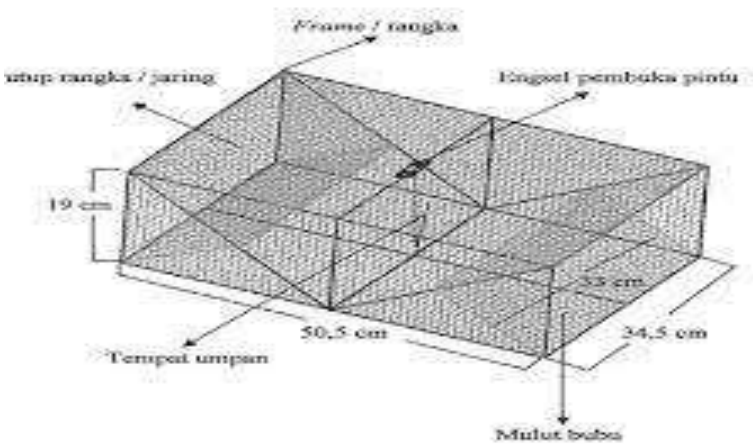

Gambar 8 Alat tangkap bubu

\section{Introdusir Alat Tangkap Bubu}

Introdusir alat tangkap bubu kepada nelayan rajungan bertujuan untuk memperkenalkan pemanfaatan dan penggunaan alat tangkap tersebut

Bubu lipat adalah alat tangkap yang dikhususkan untuk menangkap kepiting bakau (Scylla serrata), terbuat dari jaring berbentuk persegi atau kotak dengan besi sebagai rangka dan memiliki dua buah pintu sebagai tempat masuk kepiting, dapat dilipat apabila tidak sedang dioperasikan. Bubu lipat diklasifikasikan ke dalam kelompok perangkap dan penghadang. Bubu lipat sangat bermanfaat dalam mendapatkan hasil tangkapan yang banyak, sehingga perlu dikerahui cara pengoperasiannya. Berikut penjelasan lebih lanjut mengenai cara pengoperasian bubu lipat.

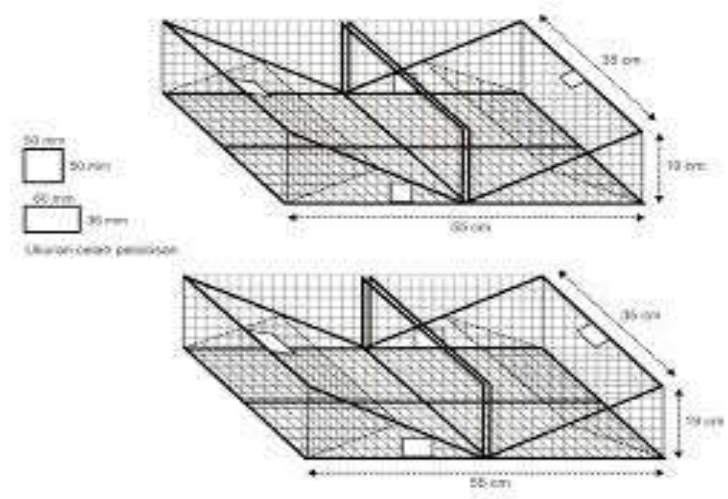

Gambar 9. Bubu lipat 


\section{Berikut cara pengoperasian Bubu Lipat}

Adapun tahapan dalam pengoperasian bubu lipat ada empat tahap, yaitu sebagai berikut .

- Pemasangan umpan. Posisi umpan harus didesain sedemikian rupa sehingga mampu menarik perhatian ikan baik dari bau maupun bentuknya. Umpan dipasang di bagian tengah bubu lipat;

- Pemasangan bubu (setting). Bubu yang telah siap diturunkan ke perairan. Sebagai penanda posisi pemasangan bubu udang dilengkapi dengan pelampung. Hal ini akan memudahkan nelayan menemukan kembali bubunya;

- Perendaman bubu (soaking). Lama perendaman bubu lipat adalah 2-3 hari, kadang bahkan sampai beberapa hari; dan

- Pengangkatan bubu (hauling). Proses hauling pada bubu dapat dilakukan dengan setelah perendaman selesai.

Sementara itu untuk meningkatkan penggunaan alat tangkap bubu dikalangan nelayan rajungan adalah melalui kerjasama (kemitraan) dengan swasta (pedagang rajunga/eksportir) untuk membantu nelayan agar penggunaan bubu lebih intensif sesuai dengan daya dukung lingkungan. Kerjasama seperti ini akan menguntungkan ke dua belah pihak yaitu nelayan dan pedagang. Pihak nelayan akan memperoleh manfaat dari bantuan bubu yang dioperasikan dan bagi pedagang tersedia rajungan untuk diekspor ke berbagai negara. Kerjasama tersebut dapat difasiltasi oleh pemerintah atau perguruan tinggi dan NGO.

Selain itu perlu adanya pembagian zonasi dalam penangkapan rajungan untuk menghindari konflik dengan nelayan yang menangkap ikan. Agar pembagian kawasan zonasi lebih efektif dalam pelaksanaannya dan mengakomoidasi semua kepentingan sebaiknya dibuat semacam aturan local (awiq-awiq).

\section{Kesimpulan}

Kesimpulan dari pelaksanaan kegiatan pengabdian pada masyarakat ini adalah :

1. Untuk mempercepat adopsi alat tangkap bubu oleh nelayan dapat dilakukan melalui skema kemitraan dan bantuan pemerintah
2. Introdusir alat tangkap bubu di kalangan nelayan akan meningkatkan pendapatan dan kelestarian lingkungan

\section{Daftar Pustaka}

Adam, Firman dan Anwar, 2016. Model Pengelolaan Perikanan Rajungan dalam Meningkatkan Pendapatan Nelayan di Kabupaten Pangkep. Jurnal Galung Tropika, 5 (3) Desember 2016, hlmn. 203 209 ISSN Online 2407-6279 . ISSN Cetak 2302-4178.

Fauzi dan Anna, 2002. Evaluasi Keber-lanjutan Pembangunan Perikanan: Apli-kasi Pendekatan RAFISH (Studi Kasus Perairan Pesisir DKI Jakarta). Jurnal Pesisir dan Lautan Vol 4 (3) 43 - 55.

Hidayat, M., Surochiem, 2008. Pokok-Pokok Strategi Pengembangan Masyarakat Pantai . Walhi Jawa Barat Official Blog.

Irwanto, 2016, Focused Group Discussion (FGD): Sebuah Pengantar Praktis. Yayasan Obor Indonesia. Jakarta.

Kementerian Kelautan dan Perikanan RI, 2016a. Statistik Ekspor Impor Direktorat Jenderal Penguatan Daya Saing ProdukKelautan dan Perikanan

Kementerian Kelautan dan Perikanan RI, $2016 b$. Statistik Perikanan 2015

Rokhmin, D., Rais, Ginting, Sitepu, 1996. Pengelolaan Sumberdaya Wilayah Pesisir dan Lautan Secara Terpadu. PT. Pradnya Paramita. Jakarta.

Santoso, D., Karnan, L. Japa, Raksun, 2016). Karakteristik

Bioekologi Rajungan (Portunus Pelagicus)

Di Perairan Dusun Ujung Lombok Timur.Jurnal Biologi Tropis, Juli 2016: Volume 16 (2):94-105 ISSN: 1411-9587 96

Tulungen, J., Kasmidi, Rotinsulu, Dimpidus, Tangkilisan, 2003. Panduan Pengelolaan Sumberdaya Wilayah Pesisir Berbasis Masyarakat. USAID-Indonesia Coastal Resoureces Managemen Project. Jakarta (https://perikanan38.blogspot.com/2021/02/ ciri-ciri-rajungan.html\#super) 